\title{
Embodied energy of conventional load-bearing walls versus natural stabilized earth blocks
}

\author{
C. Galán-Marín*, C. Rivera-Gómez, A. García-Martínez \\ Department of Building Construction, Escuela Técnica Superior de Arquitectura, University of Seville, Avda. Reina Mercedes, 2, Seville 41012, Spain
}

\section{A R T I C L E I N F O}

\section{Article history:}

Received 13 November 2014

Received in revised form 20 February 2015

Accepted 26 March 2015

Available online 9 April 2015

\section{Keywords:}

Life cycle assessment

Embodied energy

Unfired bricks

Natural composites

Sustainability

\begin{abstract}
A B S T R A C T
According to recent studies, the manufacturing and construction of the structural elements of buildings (for example, columns, beams and load-bearing walls) represent the largest proportion of embodied impacts. Some of these reports highlight the need to analyse the materials and techniques used today in order to make the building sector more sustainable. This paper presents the results of embodied energy and global warming potential, using life cycle assessment (LCA) methodology, for load-bearing walls, being these one of the most common types of structures for buildings. This study analyses through an eco-design tool new options for materials used in the construction of structural load-bearing walls. The research aims to examine the environmental performance of each material alternative assessed: fired clay brick masonry (FC), concrete block masonry (CB), reinforced concrete-based wall (RC), and stabilized soil block masonry (SS); stabilized with natural fibers and alginates. These conventional and new materials especially those with a low level of embodied energy, such as earth blocks - are evaluated from the point of view of their environmental consequences.
\end{abstract}

(c) 2015 Elsevier B.V. All rights reserved.

\section{Introduction}

Sustainable construction is a response to the growing awareness of the negative impact of buildings on the environment. Designers (architects and engineers) have an important stake as the selection of materials and construction systems are now of great importance. Due to this significant impact of the construction sector on the environment [1], different measures are now being taken to assess construction activity from a strictly environmental perspective. According to some studies, around $20 \%$ of the total impacts are related to manufacturing, construction, demolition processes and final disposal of building materials, elements and systems [2]. Long operation periods, versatility, high structural complexity and material comprehensiveness mean that buildings are treated as intricate and unique objects in ecological studies [3]. Although recent years have seen vigorous scientific evaluation of the environmental impact associated with buildings, there is still a lack of standardized environmental analysis procedures that focus on construction technologies. In this sense, the application of the life cycle assessment (LCA) $[4,5]$ helps to clarify the consequences for the environment of using certain building materials and elements such as composites, and LCA is now recognized as an important tool

\footnotetext{
* Corresponding author. Tel.: +34 954556591; fax: +34 954557018

E-mail address: cgalan@us.es (C. Galán-Marín).
}

for the environmental assessment of solutions in the construction industry.

The proper selection of building materials is important for sustainable development, and there is a clear need to design and construct buildings in a way that supports the concept of sustainable development. What is more, the environmental impact of construction material not only depends on the material itself and the other elements used in building, but also on the way they are put into place, the maintenance requirements, the system of longevity and the distance from the purchasing point to the construction site, etc. This means that the selection of materials or building systems requires the exactness of the LCA.

Energy in buildings can be categorized in two types: the amount of energy required for the maintenance/servicing of a building during its useful life operating energy (OE) and the energy capital represented by the building materials used in the production of a building embodied energy (EE). A study of both these types of energy consumption is required for a complete understanding of building energy needs. A building's embodied energy can vary greatly depending on the choice of building materials and techniques. Reinforced concrete walls, fired clay brick masonry, concrete block masonry and beam and block slabs form part of the common conventional construction systems used in the main structure of buildings in Spain. Similar building systems can be found in many other developed and developing countries. 
Alternative building technologies such as stabilized soil blocks can minimize a building's embodied energy [6-12]. Generally, the materials used to construct the structure of a building represent more than $50 \%$ of its embodied energy [13]. In this sense, the use of alternative materials, such as mortar/concrete blocks, stabilized soil blocks or fly-ashes instead of materials with high embodied energy content, like reinforced concrete, could cut cumulative energy by $20 \%$ over a building's 50 -year life cycle [14]. Recycling building materials $[15,16]$ is also essential to reducing the embodied energy level in the building, for instance, the use of recycled steel and aluminium confers can mean savings of more than $50 \%$ in embodied energy [17].

Early studies from the 1960s and 1970s focused on the life cycle stages of certain products, and emphasised the analysis of the efficiency of energy consumption and its sources, the use of raw materials and, to a lesser extent, waste disposal. For decades, such studies applied LCA analysis to construction materials due to their high potential environmental impact, and this research is reflected in current literature on the subject. Energy requirements for the production and processing of different building materials, $\mathrm{CO}_{2}$ emissions and the implications for the environment have been studied by Buchanan and Honey [18], Suzuki et al. [19], Oka et al. [20], Debnath et al. [21], Pargana et al. [22] and Praseeda et al. [23]. Some researchers have analysed the proportion of embodied energy in materials used, and carried out LCAs of existing conventional buildings $[24,25]$. Other approaches and simplifications have also been applied in LCAs for building materials [26], and there are numerous studies in which LCA is used to evaluate the impact of different construction materials and solutions [27-30].

\section{Research aim and methods}

Most part of the papers available in literature use LCA tool in case studies due to the need to fully define all the variables within the limits of the analysis [31-37]. In other cases, research is done by means of a LCA theoretical study through a literature review [22,38-41]. Moreover, other researchers limit the LCA applicable results to a specific climate area [42] or a specific regulatory environment [40]. And there are also models of analysis seeking to apply LCA tool to obtain improvements in the design of the processes of manufacturing and construction $[43,44]$. This study is not intended to reach the definition level of a given case study but to support designers' environmental concerns establishing a first approximation using the parallelism between structural parameters and LCA of different materials commonly used in load-bearing walls.

Industries that produce building material are considered to be among the largest fuel consumers in the economy, so savings in fuel consumption in this sector could have a substantial impact on an economy's total fuel demand [45]. Moreover, environmental assessments that include the energy used in the production of building materials are vital for extending the life cycle of the product. Environmental assessments of building material production can provide criteria for design decisions when choosing between materials that offer a similar performance for a given application [46]. In this regard, the energy consumption resulting from the manufacturing process of building materials is important in terms of LCA. Materials that require high production temperatures, such as concrete or ceramic, have a big negative impact compared to those whose production temperature is low or zero.

Our study takes an environmental perspective when comparing various conventional technologies for building walls to others that use new low-impact materials. By identifying and quantifying the materials used in the manufacturing processes and applying LCA methodology, we identify the environmental impact of each building alternative studied. Summing up, our study identifies the processes involved in each technology, quantifies their associated impact and compares their environmental performance.

The aim of this research is to compare the environmental aspects and potential impact associated with the construction, maintenance and disposal of walls in three-storey buildings, determining the option with the lowest negative impact in relation to mechanical and structural characteristics. A life cycle assessment was made of three models of housing blocks erected with loadbearing walls that varied according to their material structure. The options compared involved conventional and unconventional building materials, therefore, the study analysed:

- fired clay brick masonry (FC),

- concrete block masonry (CB),

- reinforced concrete-based wall (RC),

- stabilized soil block masonry (SS).

\section{The conventional and unconventional materials used}

All construction material is manufactured from a combination of raw materials that involve energy expenditure and associated waste. Therefore, the energy cost of manufacturing building materials is an essential element in computing environmental impact, and manufacture is probably the element most widely cited when considering the environmental impact of construction materials. This analysis raises typical questions such as: Are the raw materials renewable? Are they scarce? Are they important to the global environment? How much energy is required and how much waste is produced in the manufacture? What impact does this waste have on the environment?. The construction process also involves energy expenditure and produces waste, and also poses more important questions: How much manufactured material is used? Can materials that cause less environmental impact be deployed? How much energy is used? How much waste is produced? What is the environmental impact of the waste? Such questions can only be answered according to the specific structure to which they are applied. Increasing attention is now being given to the construction phase as part of efforts to make construction more sustainable.

To establish a comparative standard, we have chosen common, and not so common, building materials widely used for a specific building typology: Fired clay brick masonry (FC); concrete block masonry (CB), reinforced concrete-based wall (RC), and, the least common element, stabilized soil block masonry (SS). The features of the different construction systems are explained in the following sections.

\subsection{Fired clay bricks}

Bricks are made by shaping a plastic mass of clay and water which is later solidifies by drying and firing. Bricks are among the oldest and most enduring of mankind's building materials. They require a considerable amount of thermal energy during the firing process because they burn at temperatures of between 1000 and $1200^{\circ} \mathrm{C}$, depending on the clay type. Light-coloured clays usually require higher firing temperatures than dark-coloured ones. This thermal energy amounts to 3.75-4.75 MJ per brick [47]. We applied an average value of $4.25 \mathrm{MJ}$ per brick (standard size in Spain: $240 \mathrm{~mm} \times 115 \mathrm{~mm} \times 70 \mathrm{~mm}$ ) for the comparison and computation of the energy content of buildings and masonry.

\subsection{Concrete blocks}

Light-weight/low-density concrete blocks are commonly used in the construction of envelope walls in multi-storey buildings. They are also used to a lesser extent to build load-bearing masonry walls. The basic composition of the blocks is cement, sand and 
coarse aggregates (less than $4 \mathrm{~mm}$ size). The energy content of the block will mainly depend on the cement percentage. Energy spent in crushing the coarse aggregate also contributes to the block energy calculation. The percentage of cement generally varies between 7 and $10 \%$ by weight. The quality of the block, particularly the compressive strength, is the deciding factor in the percentage of cement used. The energy content of a concrete block measuring $400 \mathrm{~mm} \times 200 \mathrm{~mm} \times 200 \mathrm{~mm}$ will be in the range of $12.3-15.0 \mathrm{MJ}$ [47].

\subsection{Reinforced concrete wall}

Concrete is manufactured from aggregates (rock and sand), hydraulic cement and water. It usually contains a small amount of chemical admixture, and often has a mineral admixture that replaces a portion of the cement. A typical concrete formulation contains a large quantity of coarse and fine aggregates, a moderate amount of cement and water, and a small percentage of admixture. Most of these constituents are themselves manufactured products, by-products, or materials extracted by mining. In order to assess the environmental impact of concrete manufacture, it is necessary to consider the impact of each separate constituent. The constituent with the highest environmental impact is cement. Portland cement is usually manufactured by heating a mixture of limestone and shale in a kiln to a high temperature (approximately $1500^{\circ} \mathrm{C}$ ), then intergrading the resulting clinker with gypsum to form a fine powder. Thus, it is not surprising that the embodied energy in Portland cement is high. The average value of the energy required to make cement stands at about $5.85 \mathrm{MJ} / \mathrm{kg}$. The energy required for concrete manufacture, considering all constituents, yields an average energy expenditure of $1.4 \mathrm{MJ} / \mathrm{kg}$ [47]. Reinforced concrete is made with steel rods, and the energy consumed in the steel production is $42 \mathrm{MJ} / \mathrm{kg}$ [47].

\subsection{Stabilized soil blocks}

The stabilized soil blocks considered in this research are made from a combination of clay soil, water, a natural polymer as stabilizer and animal fiber reinforcement. The polymer used is calcium alginate, which is added to the mixture in the proportion of $1.2 \%$ by weight. Calcium alginate is a chemical synthesis of wet chopped seaweed and calcium chloride and sodium carbonate. The animal fibre is raw cut wool, unwashed and unprocessed, and the proportion used is $0.25 \%$ by weight. The blocks are cured at room temperature. The energy consumption is based mainly on transport and extraction because they are not fired or steam-cured.

\subsection{Mortar}

Mortar is a mixture of cementitious material and sand. It is used for the construction of masonry as well as plastering and rendering works. According the European standard [48], the mortar used for masonry must have a compressive strength of $7.5 \mathrm{~N} / \mathrm{mm}^{2}$, equivalent to a cement-sand ratio of $1-5$. This ratio represents energy consumption in the production of $1300 \mathrm{MJ} / \mathrm{m}^{3}$ [47].

\subsection{Embodied energy in the models proposed}

Considering that three out of four wall types are masonry-based and the other is a combination of concrete and steel, the energy consumption is the sum of the proportions of the different components for each model. Masonry is an assemblage of masonry units (such as bricks/blocks) and mortar. The individual volumes of these two components will depend mainly on the size of the masonry unit. The energy content of the masonry should include that of the masonry units as well as the mortar. Reinforced concrete used in

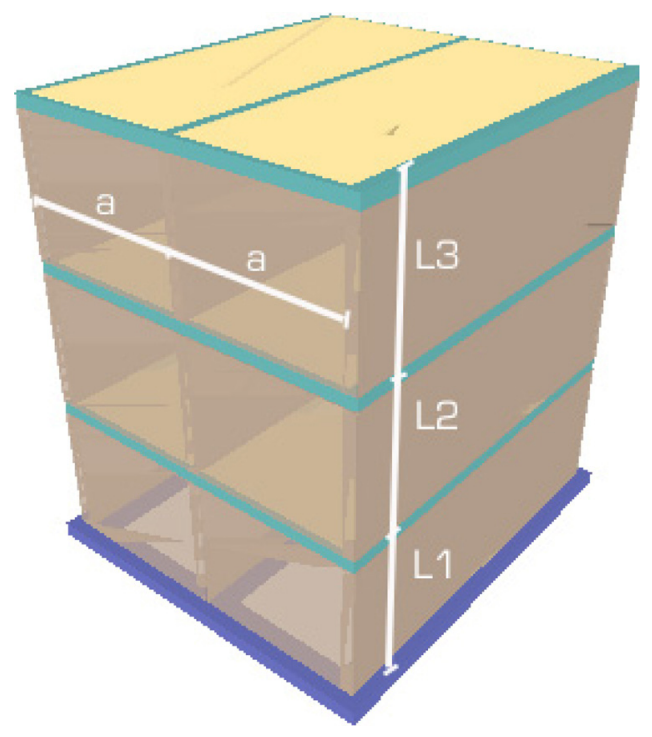

Fig. 1. Scheme of the building analysed: " $a$ " represents the span (from 3.00 to $4.50 \mathrm{~m})$. L1, L2, L3 represent the height of the different levels.

walls will have a steel/concrete proportion related to the resistance required according to the use to which it is put in the construction.

\section{Structural parameters}

As a study hypothesis, a three-storey building (ground floor + two, see Fig. 1) was chosen as it is a common housing type. The structure of the building is supported by load-bearing walls. An initial variable in terms of the constituent material of the wall is established: fired clay brick masonry (FC); concrete block masonry (CB), reinforced concrete wall (RC) and stabilised soil block masonry (SS). A second variable is the distance between the walls (span): $3.00 \mathrm{~m}, 3.50 \mathrm{~m}, 4.00 \mathrm{~m}$ and $4.50 \mathrm{~m}$, these being the most common dimensions for this building typology (Table 1). The size of the construction system is calculated in mechanical terms by determining the section of the ground floor's load-bearing walls.

The software used to establish the structure of the models proposed is CYPECAD ${ }^{\circledR}$, which is used for the analysis and design of building structures in homes, buildings and civil engineering projects that have horizontal and vertical loads. This program is adapted to international regulations and automatically generates hypotheses for any user-defined combination according to the stated premises. Users can also define their own project situations to personalize the combinations to be taken into account in the calculations for the structural elements of the project. Entering data such as the physical parameters of the different materials and the building characteristics in the software gives us the wall dimensions, as shown in Table 2.

\section{Scope of the LCA}

Both types of energy consumption operating energy (OE) and embodied energy (EE), are required for a complete understanding of building energy needs. Building EE specifically can also vary greatly depending on the choice of building materials and techniques at a very early design stage. Moreover, a building wall as an envelope is not just the a bearing wall but commonly composed of a multi-layered system in order to fulfil the standards requirements in terms of conditions of comfort which would introduce other variables in the study such as type and thickness of insulation to be used, quite far from the scope of this study. This study intends to limit the LCA tool taking into account that the present 
Table 1

Floor area of the building analysed.

\begin{tabular}{|c|c|c|c|c|c|}
\hline & \multicolumn{4}{|l|}{ Span } & \multirow{2}{*}{$\begin{array}{l}\text { Span average }(\mathrm{m}) \\
3.75\end{array}$} \\
\hline & a3.00 (3 m) & a3.5 $(3.5 \mathrm{~m})$ & $\mathrm{a} 4(4.0 \mathrm{~m})$ & $\mathrm{a} 4.5(4.5 \mathrm{~m})$ & \\
\hline Level L1 & 48 & 56 & 64 & 72 & 60 \\
\hline Level L2 & 96 & 112 & 128 & 144 & 120 \\
\hline Level L3 & 144 & 168 & 192 & 216 & 180 \\
\hline Floor area $\left(\mathrm{m}^{2}\right)$ & & & & & \\
\hline
\end{tabular}

Table 2

Summary of the mean values of the walls' thickness and total mass obtained for each load-bearing wall construction after structural calculations.

\begin{tabular}{|c|c|c|c|c|c|c|c|c|c|c|}
\hline & \multirow{2}{*}{$\begin{array}{l}\text { Compressive } \\
\text { strength } \\
(\mathrm{MPa})\end{array}$} & \multirow[t]{2}{*}{$\begin{array}{l}\text { Density } \\
\left(\mathrm{g} / \mathrm{cm}^{2}\right)\end{array}$} & \multicolumn{5}{|c|}{$\begin{array}{l}\text { Medium value of the walls' thickness }(\mathrm{cm}) \\
\text { Span between walls }\end{array}$} & \multicolumn{3}{|c|}{$\begin{array}{l}\text { Total wall mass }(\mathrm{kg}) \\
\text { Span between walls }\end{array}$} \\
\hline & & & $3.0 \mathrm{~m}$ & $3.5 \mathrm{~m}$ & $4.0 \mathrm{~m}$ & $4.5 \mathrm{~m}$ & $3.0 \mathrm{~m}$ & $3.5 \mathrm{~m}$ & $4.0 \mathrm{~m}$ & $4.5 \mathrm{~m}$ \\
\hline FC & 5.00 & 1.40 & 0.29 & 0.29 & 0.33 & 0.38 & 122.107 & 122.107 & 140.431 & 145.453 \\
\hline $\mathrm{CB}$ & 4.00 & 1.50 & 0.20 & 0.23 & 0.25 & 0.35 & 47.098 & 53.865 & 57.248 & 57.248 \\
\hline $\mathrm{RC}$ & 25.00 & 2.50 & 0.25 & 0.25 & 0.25 & 0.25 & 130.996 & 130.996 & 130.996 & 130.996 \\
\hline SS & 4.45 & 1.79 & 0.28 & 0.30 & 0.32 & 0.33 & 115.062 & 121.830 & 128.599 & 142.136 \\
\hline
\end{tabular}

Note: FC: fired clay brick masonry; CB: concrete block masonry; RC: reinforced concrete-based wall; SS: stabilized soil block masonry.

research is not focused on a case study analysis. Hence it is not possible to calculate $\mathrm{OE}$ (considering insulation, depending on the transmittance of the wall elements, etc). By contrast this study is a first approximation that links embodied energy and global warming potential with resistance parameters in different construction materials used for building structures.

The aim of the LCA applied in this study is to obtain the values for the embodied energy and global warming potential (GWP) impact categories associated with the construction of four types of loadbearing wall: fired clay brick masonry (FC), concrete block masonry (CB), reinforced concrete-based wall (RC) and stabilised soil block masonry (SS). We evaluated a three-storey building whose total height is $9.90 \mathrm{~m}$. The construction consists of three parallel walls each $8.00 \mathrm{~m}$ long. The distances between the walls are $3.00 \mathrm{~m}$, $3.50 \mathrm{~m}, 4.00 \mathrm{~m}$ and $4.50 \mathrm{~m}$.

In terms of the proposed framework, this study should yield results that answer the question: what is the environmental impact of the processes related to the construction of each combination proposed?

According to the study aim, the functional unit is the total surface of the walls in each case.

The system assessed is composed of each process in the production, construction, maintenance, deconstruction and final disposal of all components of the building structure. It does not include those processes related to the operational phase of the dwelling. The system includes the following processes:

- Manufacture of building products. For each building material involved in the construction, all goods and services provided from beginning to end are considered. Machine manufacture and territorial infrastructure processes have also been taken into account.

- Assembly and construction. This covers the processes that integrate all products and services on site in each of the dwellings studied. The transportation of building materials from factory to site, and the placement of building products are also evaluated.

- Maintenance and repair. This includes all repair operations and maintenance of building components, also taking into account the replacement of those materials that are less durable.

- Dismantling and demolition. The study evaluates all processes at the end of the life of the building that involve the dismantling and demolition of the dwelling: demolition, removal of building elements and transportation of demolition materials for recycling or disposal.
- Disposal and recycling. This covers all processes involving material following dismantling and demolition, that is, the deconstruction of building materials.

The environmental data on wool and algae are found in recent studies by Biswas et al. [49] and Resurreccion et al. [50]. The environmental data concerning the rest of the building materials come from the Ecoinvent V.2 database [47].

The calculation procedure to obtain the life cycle inventory is described by Zabalza [51] and García [52] as follows:

1. Identification and quantification of the initial building products and auxiliary materials - including replacement materials - involved in the life cycle. The quantities of building materials has been calculated as follows:

a. The materials required to build each type of wall have been determined. The building materials are defined in Section 3. As overview, the following materials take part:

Fired clay brick masonry (FC): cement, water, sand, hydraulic lime, bricks.

Concrete block masonry (CB): cement, water, sand, concrete blocks

Reinforced concrete-based wall (RC): concrete, reinforced steel in bars; steel, saw timber and solvents in formwork.

Stabilized soil block masonry (SS): clay plaster, algae, wool.

b. The thickness of each load bearing wall is calculated considering the structural parameters defined in Section 4.

c. The quantities of building materials (i.e. mortar, concrete blocks, formwork or reinforced steel) are obtained for each type of wall.

2. Identification and quantification of the basic processes associated with construction and deconstruction. Depending on the volume of material used in construction, and by applying the ratios set by Kellenberger et al. [53], the energy (electricity power and diesel used in building machines) used in the operations of construction, maintenance and demolition of each model is obtained. The processes related to transport are obtained by determining the mass of material transported associated with each material used, and considering the distance from factory to site and from the site to landfill. Were considered medium distances for each material, assuming an urban construction site according to the method described by Garcia [52]. Finally, the processes associated with the end of life of the materials used 
Table 3

Inventory list of the materials used and corresponding name in the Ecoinvent V.2. database. Unitary values for global warming potential and embodied energy.

\begin{tabular}{|c|c|c|c|c|c|}
\hline Component & ID & Name (Ecoinvent) & Ud & $\begin{array}{l}\text { Global Warming } \\
\text { Potential 100a CML } \\
2001 \mathrm{~kg} \mathrm{CO}-\mathrm{Eq}\end{array}$ & $\begin{array}{l}\text { Embodied Energy } \\
\text { Cumulative Energy } \\
\text { Demand MJ }\end{array}$ \\
\hline Solvent & 443 & $\begin{array}{l}\text { Solvents, organic, } \\
\text { unspecified, at plant }\end{array}$ & $\mathrm{kg}$ & 2.12 & 65.77 \\
\hline Sand & 464 & Gravel, round, at mine & $\mathrm{kg}$ & 0.00 & 0.06 \\
\hline Cement & 484 & $\begin{array}{l}\text { Cement, unspecified, at } \\
\text { plant }\end{array}$ & $\mathrm{kg}$ & 0.77 & 3.56 \\
\hline Hydraulic lime & 488 & Lime, hydraulic, at plant & $\mathrm{kg}$ & 0.83 & 4.82 \\
\hline Brick & 495 & Brick, at plant & $\mathrm{kg}$ & 0.22 & 2.84 \\
\hline Concrete & 504 & Concrete, normal, at plant & $\mathrm{m}^{3}$ & 265.22 & 1447.23 \\
\hline Concrete block & 537 & Cement mortar, at plant & $\mathrm{kg}$ & 0.20 & 1.52 \\
\hline Clay & 538 & Clay plaster, at plant & $\mathrm{kg}$ & 0.02 & 0.52 \\
\hline Diesel (Const.-Dem.) & 559 & $\begin{array}{l}\text { Diesel, burned in building } \\
\text { machine }\end{array}$ & MJ & 0.09 & 1.38 \\
\hline Electricity (Const.-Dem.) & 698 & Electricity mix, Spain & $\mathrm{kWh}$ & 0.50 & 10.90 \\
\hline Reinforced steel & 1.141 & Reinforcing steel, at plant & $\mathrm{kg}$ & 1.34 & 20.94 \\
\hline Steel formwork & 1.141 & Reinforcing steel, at plant & $\mathrm{kg}$ & 1.34 & 20.94 \\
\hline Metal packing & 1.154 & Steel, low-alloyed, at plant & $\mathrm{kg}$ & 1.63 & 26.16 \\
\hline Steel wire & 1.154 & Steel, low-alloyed, at plant & $\mathrm{kg}$ & 1.63 & 26.16 \\
\hline Supplementary mat. & 1.154 & Steel, low-alloyed, at plant & $\mathrm{kg}$ & 1.63 & 26.16 \\
\hline Transport & 1.943 & Transport, lorry $32 \mathrm{t}$ & tkm & 0.17 & 2.81 \\
\hline Plasticizer & 1.998 & $\begin{array}{l}\text { Alkylbenzene sulfonate, } \\
\text { linear, petrochemical, at } \\
\text { plant }\end{array}$ & $\mathrm{kg}$ & 1.53 & 59.97 \\
\hline Final disposal & 2.221 & $\begin{array}{l}\text { Disposal, inert material, } 0 \% \\
\text { water, to sanitary landfill }\end{array}$ & $\mathrm{kg}$ & 0.01 & 0.33 \\
\hline Water & 2.288 & Tap water, at user & $\mathrm{kg}$ & 0.00 & 0.01 \\
\hline Saw timber & 2.507 & $\begin{array}{l}\text { Sawn timber, softwood, } \\
\text { planed, kiln dried, at plant }\end{array}$ & $\mathrm{m}^{3}$ & -713.13 & $12,792.19$ \\
\hline Algae & A001 & $\begin{array}{l}\text { Algae, at regional } \\
\text { storehouse }^{\mathrm{a}}\end{array}$ & $\mathrm{kg}$ & 0.0200 & 20.0000 \\
\hline Sheep wool & P001 & Wool mat, at plant ${ }^{\mathrm{b}}$ & $\mathrm{kg}$ & 15.2600 & 24.9150 \\
\hline
\end{tabular}

a Data provided by Resurreccion et al. [50].

b Data provided by Biswas et al. [49].

are determined. For this final stage, disposal in a landfill scenario is established.

3. Determination of input and output of each unit process. The Ecoinvent V.27. database and published LCA studies [41,49-51] has been used to obtain environmental information on each unit process. Each identified unitary process is assigned the value of global warming potential (GWP) and cumulative energy demand. Table 3 shows the unitary values for GWP and primary embodied energy of the materials used.

4. Inventory and Assessment. Table 4 shows the inventory of the materials used for each type of construction. The impact assessment was carried out using the CML 2001 method in relation to the GWP impact category, and the "cumulative energy demand" calculation was used to obtain primary embodied energy.

\section{Results and discussion}

A graphic comparison of embodied energy values and the global warming potential of the individual wall types is shown in Figs. 2-7 and a extensive list of the values in Table 5.

Regarding cumulative energy demand, for a three-levels building, fired clay brick wall constructions (FC) score highest and concrete block walls (CB) the lowest. The mean values for each type were 395,834.71 MJ and 145,027.43 MJ respectively. The mean values for stabilized soil walls (SS) and reinforced concrete walls (RC) were 266,562.54 MJ and 309,213.86 MJ. The contribution of the manufacturing phase to these results is significant, representing mean percentages in relation to the total stages that range from $38.11 \%$ (SS) to $51.59 \%$ (FC). The construction phase is also important, representing more than $25 \%$ in all cases. Comparative results are similar for the global warming potential impact category for a three-levels building: fired brick wall constructions (FC) again score highest and concrete block walls (CB) the lowest. The mean values for each type were $29,188.97 \mathrm{~kg}$ eq- $\mathrm{CO}_{2}$ and $13,716.86 \mathrm{~kg}$ eq- $\mathrm{CO}_{2}$. The mean values for stabilized soil walls (SS) and reinforced concrete wall (RC) were $16,201.10 \mathrm{~kg}$ eq- $\mathrm{CO}_{2}$ and $27,505.15 \mathrm{~kg}$ eq $-\mathrm{CO}_{2}$. The contribution of the manufacturing phase to these results is also significant, with average percentages in relation to the total stages ranging from $44.07 \%$ (SS) to $71.83 \%$ (FC). The construction phase also contributes significantly to the total impact, with mean values spanning $16.53 \%(\mathrm{CB})$ and $31.93 \%$ (SS).

Looking at Table 5 it can be seen that the $\mathrm{GWP} / \mathrm{m}^{2}$ obtained for the average of the three levels studied is higher for the RC 153.24 and slightly lower for FC 146.21 , with the SS 79.68 being half the RC and almost double the CB 47.83. Variations from the CED when considering the four materials slightly modify this rate being FC $1957.62 \mathrm{MJ}$ the highest average consumption followed by RC 1793.65 MJ. The ratio between the results of SS $1303.64 \mathrm{MJ}$ and CB $736.04 \mathrm{MJ}$ is virtually identical with respect to energy consumption and $\mathrm{CO}_{2}$ emissions, being SS double vs. $\mathrm{CB}$.

If the three levels are analysed independently, the main consideration to be taken into account is the practical equivalence of emissions between SS and CB for one store height buildings (1 level) mainly due to the decrease in thickness required for SS blocks. The higher the building height, the higher the difference between the proportions of $\mathrm{CO}_{2}$ emissions between $\mathrm{CB}$ and SS. Moreover, this better behaviour of SS for GWP for low structures is less favourable in the case of CED.

To evaluate the results shown in Table 5, the first question to be addressed is the relationship between the compressive strength of the different wall materials, hence the various thicknesses required for the ground floor level walls and the distances between the walls. For the comparison we took as a starting point the fact that the strength of fired clay brick masonry and stabilized soil block 
Table 4

Inventory list of the construction materials used.

\begin{tabular}{|c|c|c|c|c|c|c|}
\hline \multirow[t]{2}{*}{ Wall type } & \multirow[t]{2}{*}{ Component } & \multirow[t]{2}{*}{ Id } & \multirow[t]{2}{*}{ Ud } & \multicolumn{3}{|c|}{ Average values per building } \\
\hline & & & & 1 Floor & 2 Floors & 3 Floors \\
\hline \multirow[t]{9}{*}{$\mathrm{FC}$} & Sand & 464 & $\mathrm{~kg}$ & $15,281.65000$ & $35,109.93500$ & $59,484.84500$ \\
\hline & Cement & 484 & $\mathrm{~kg}$ & 1987.63000 & 2981.44500 & 2981.44500 \\
\hline & Brick & 495 & $\mathrm{~kg}$ & $15,289.20000$ & $34,372.80000$ & $58,506.30000$ \\
\hline & Diesel (Const.-Dem.) & 559 & MJ & $16,244.20841$ & $36,847.69204$ & $62,406.82722$ \\
\hline & Electricity (Const.-Dem.) & 698 & $\mathrm{kWh}$ & 717.74280 & 1628.09815 & 2757.41667 \\
\hline & Transport & 1943 & $\mathrm{tkm}$ & 3459.45500 & 7835.09150 & $13,252.50278$ \\
\hline & Plasticizer & 1998 & $\mathrm{~kg}$ & 9.92000 & 14.88500 & 14.88500 \\
\hline & Final Disposal & 2221 & $\mathrm{~kg}$ & $34,594.55000$ & $78,350.91500$ & $132,524.65324$ \\
\hline & Water & 2288 & $\mathrm{~kg}$ & 2026.15000 & 4700.55500 & 8023.21000 \\
\hline \multirow[t]{11}{*}{$\mathrm{CB}$} & Sand & 464 & $\mathrm{~kg}$ & 1713.83000 & 3427.66000 & 5141.49000 \\
\hline & Cement & 484 & $\mathrm{~kg}$ & 222.91000 & 445.82000 & 668.74000 \\
\hline & Concrete block (20.20.40) & 537 & $\mathrm{~kg}$ & $13,534.20000$ & $27,068.40000$ & $30,451.95000$ \\
\hline & Concrete block (30.20.40) & 537 & $\mathrm{~kg}$ & 0.00000 & 0.00000 & 5075.32500 \\
\hline & Concrete block (35.20.40) & 537 & $\mathrm{~kg}$ & 0.00000 & 0.00000 & $11,842.42500$ \\
\hline & Diesel (Const.-Dem.) & 559 & MJ & 5828.86346 & $11,657.73548$ & $19,897.39043$ \\
\hline & Electricity (Const.-Dem.) & 698 & $\mathrm{kWh}$ & 257.54562 & 515.09163 & 879.15695 \\
\hline & Transport & 1943 & $\mathrm{tkm}$ & 1569.92800 & 3139.85700 & 5386.49700 \\
\hline & Plasticizer & 1998 & $\mathrm{~kg}$ & 1.11000 & 2.23000 & 3.34000 \\
\hline & Final Disposal & 2221 & $\mathrm{~kg}$ & $15,699.28000$ & $31,398.57000$ & $53,864.97000$ \\
\hline & Water & 2288 & $\mathrm{~kg}$ & 227.23000 & 454.46000 & 681.70000 \\
\hline \multirow[t]{7}{*}{ SS } & Clay & 538 & $\mathrm{~kg}$ & $133,488.00000$ & $70,081.20000$ & $125,145.00000$ \\
\hline & Diesel (Const.-Dem.) & 559 & MJ & $48,528.97155$ & $25,477.71007$ & $45,495.91083$ \\
\hline & Electricity (Const.-Dem.) & 698 & $\mathrm{kWh}$ & 2144.23006 & 1125.72078 & 2010.21568 \\
\hline & Transport & 1943 & $\mathrm{t} \mathrm{km}$ & $14,382.36000$ & 7550.73900 & $13,483.46250$ \\
\hline & Final Disposal & 2221 & $\mathrm{~kg}$ & $135,367.20000$ & $71,067.78000$ & $126,906.75000$ \\
\hline & Algae & A001 & $\mathrm{kg}$ & 1555.20000 & 816.48000 & 1458.00000 \\
\hline & Sheep wool & P001 & $\mathrm{kg}$ & 324.00000 & 170.10000 & 303.75000 \\
\hline \multirow[t]{12}{*}{ RC } & Solvent & 443 & $\mathrm{~kg}$ & 38.88000 & 116.64000 & 116.64000 \\
\hline & Concrete & 504 & $\mathrm{~m}^{3}$ & 18.54000 & 55.62000 & 55.62000 \\
\hline & Diesel (Const.-Dem.) & 559 & $\mathrm{MJ}$ & $16,199.48120$ & $48,581.53378$ & $48,598.44184$ \\
\hline & Electricity (Const.-Dem.) & 698 & $\mathrm{kWh}$ & 715.76655 & 2146.55250 & 2147.29957 \\
\hline & Reinforced steel & 1141 & $\mathrm{~kg}$ & 192.46000 & 384.91000 & 577.37000 \\
\hline & Steel formwork & 1141 & $\mathrm{~kg}$ & 576.00000 & 1728.00000 & 1728.00000 \\
\hline & Metal packing & 1154 & $\mathrm{~kg}$ & 3.50000 & 1.78000 & 10.50000 \\
\hline & Steel wire & 1154 & $\mathrm{~kg}$ & 0.89000 & 10.50000 & 2.67000 \\
\hline & Supplementary mat. & 1154 & $\mathrm{~kg}$ & 9.99000 & 29.51000 & 29.96000 \\
\hline & Transport & 1943 & $\mathrm{t} \mathrm{km}$ & 5100.92300 & $15,282.77950$ & $15,302.76250$ \\
\hline & Final Disposal & 2221 & $\mathrm{~kg}$ & $47,373.32000$ & $141,926.14000$ & $142,119.94000$ \\
\hline & Saw timber & 2507 & $\mathrm{~m}^{3}$ & 0.28800 & 0.86400 & 0.86400 \\
\hline
\end{tabular}

masonry is quite similar (between 5.00 and $4.00 \mathrm{MPa}$ ), while that of reinforced concrete-based walls is five times higher (25 MPa). This difference assumes a slight alteration in thickness in the case of short distances between the walls but which will increase as the distances become greater. This variation means that reinforced concrete-based walls are much thinner (20-40\% less) over bigger distances $(4.5 \mathrm{~m})$ than the rest of the building materials used for making comparisons in this research.

Another relevant issue is the influence of the block or brick format and the constituent materials of the walls. In this case, this difference results in the concrete block masonry having less than half the mass of the remaining walls. The factor sees an increase in

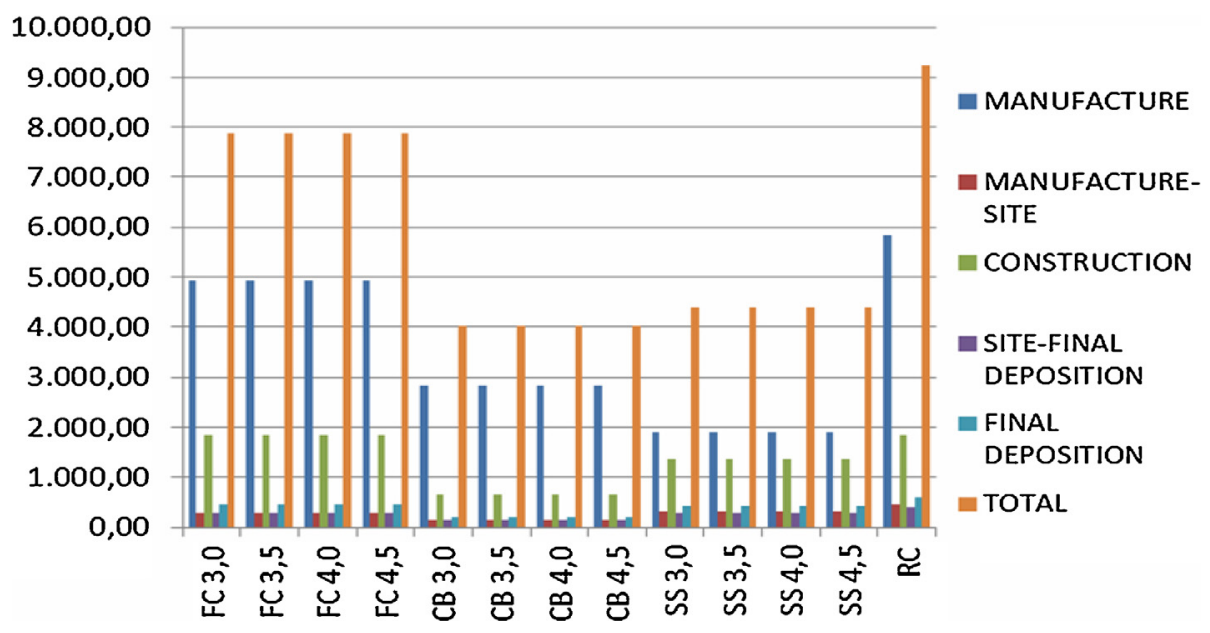

Fig. 2. GWP 100a (kg eq- $\mathrm{CO}_{2}$ ) for each type of load-bearing wall for the one-level model. 


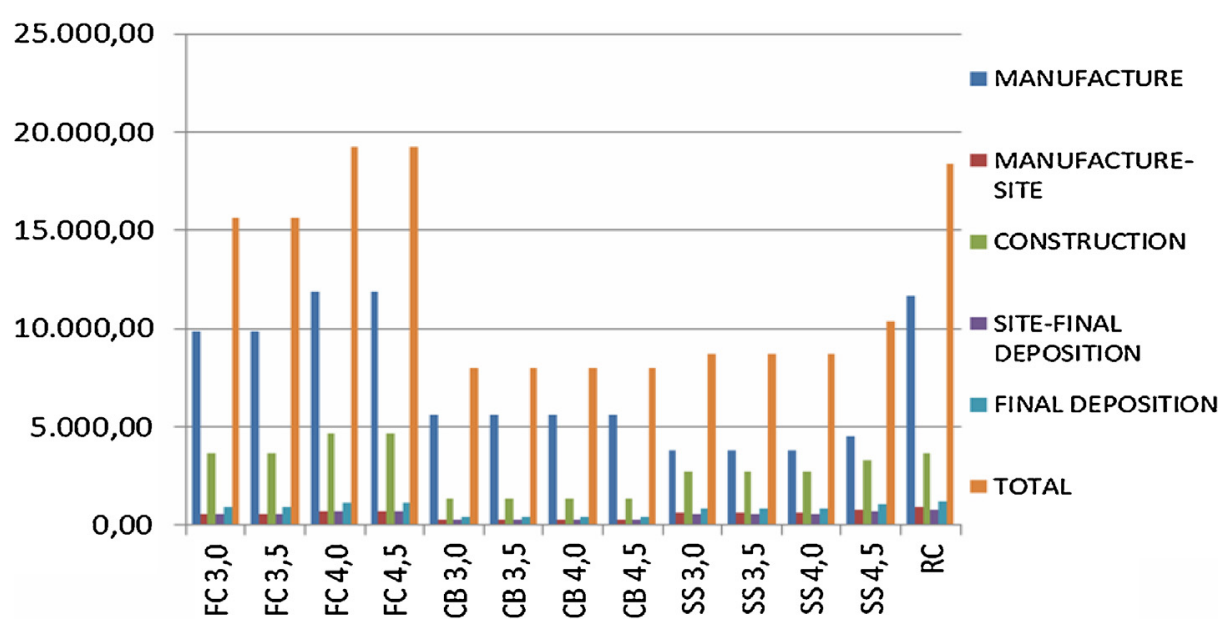

Fig. 3. GWP $100 \mathrm{a}\left(\mathrm{kg}\right.$ eq- $\left.\mathrm{CO}_{2}\right)$ for each type of load-bearing wall for the two-levels model.

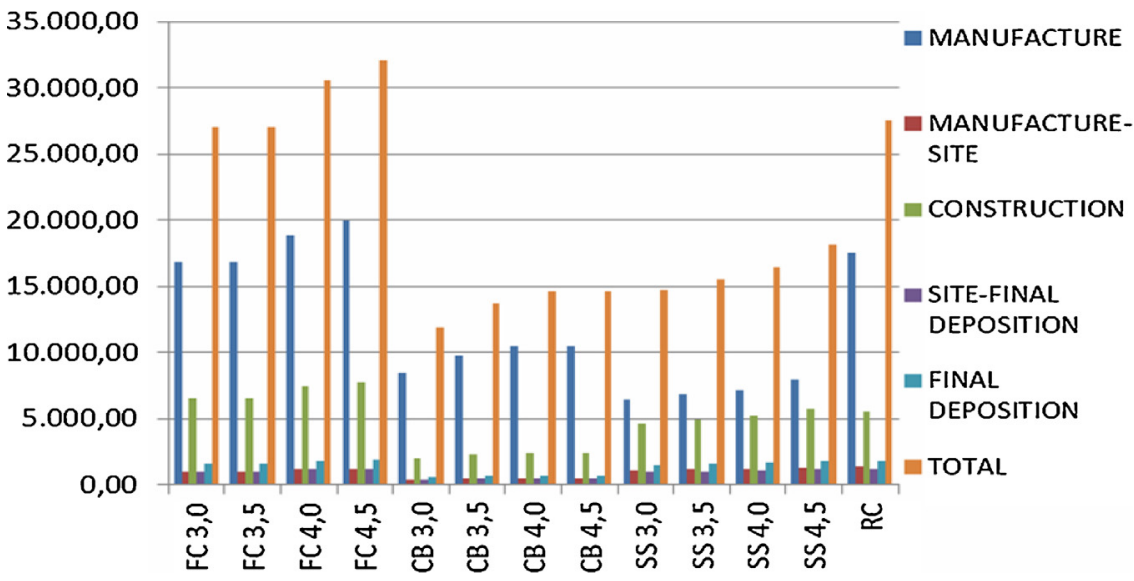

Fig. 4. GWP $100 \mathrm{a}\left(\mathrm{kg}\right.$ eq- $\left.\mathrm{CO}_{2}\right)$ for each type of load-bearing wall for the three-levels model.

mass of up to three times between reinforced concrete-based walls and concrete block masonry (for a $3.0 \mathrm{~m}$ distance), and between fired clay bricks masonry and concrete block masonry (for a distance of $4.5 \mathrm{~m}$ ). There is no linear increase in the difference between the mass of the materials and the widening between walls.

In this study wall dimensions were decided just by means of structural calculations. However, in addition to satisfying the structural requirement, the outer building walls also have to fulfil other requirements as a building envelope. In this case the thermal parameters (such as heat transfer coefficient) of the walls should be taken into account before running LCA. In any case, the inclusion of the thermal conductivity variables would require selecting the examples proposed through a more defined case study. Thus the differences between inner and outer walls should be considered and so complementary materials for insulation or thermal comfort could be included to fulfil the requirements due to a given climatic zone. These variations would imply a new perspective for the present investigation and for an specific case quite possibly

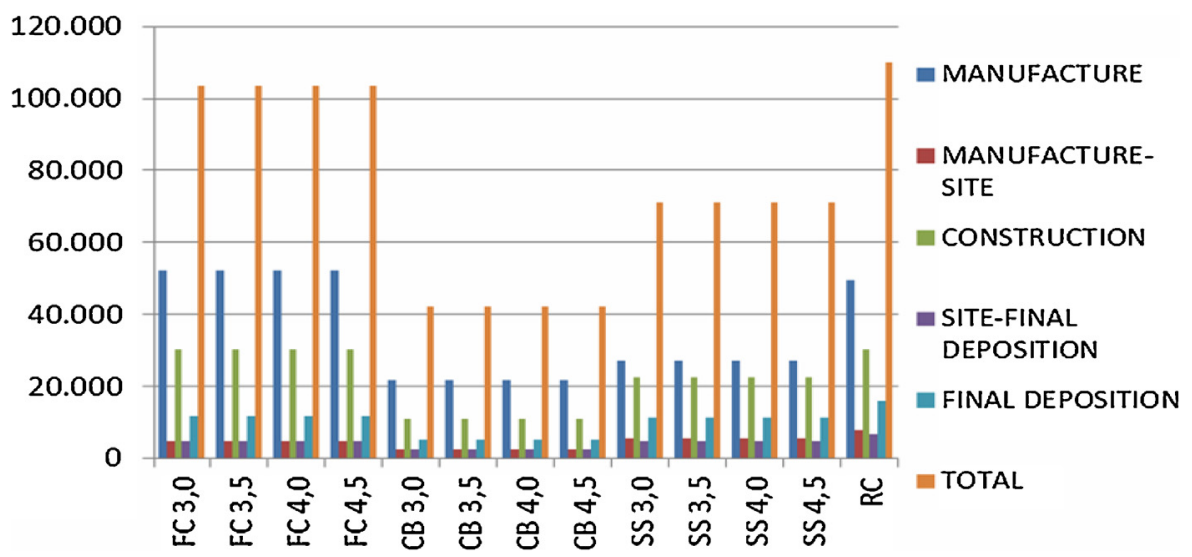

Fig. 5. Cumulative energy demand (MJ) GWP $100 \mathrm{a}\left(\mathrm{kg}\right.$ eq- $\left.\mathrm{CO}_{2}\right)$ for each type of load-bearing wall for the one-level model. 


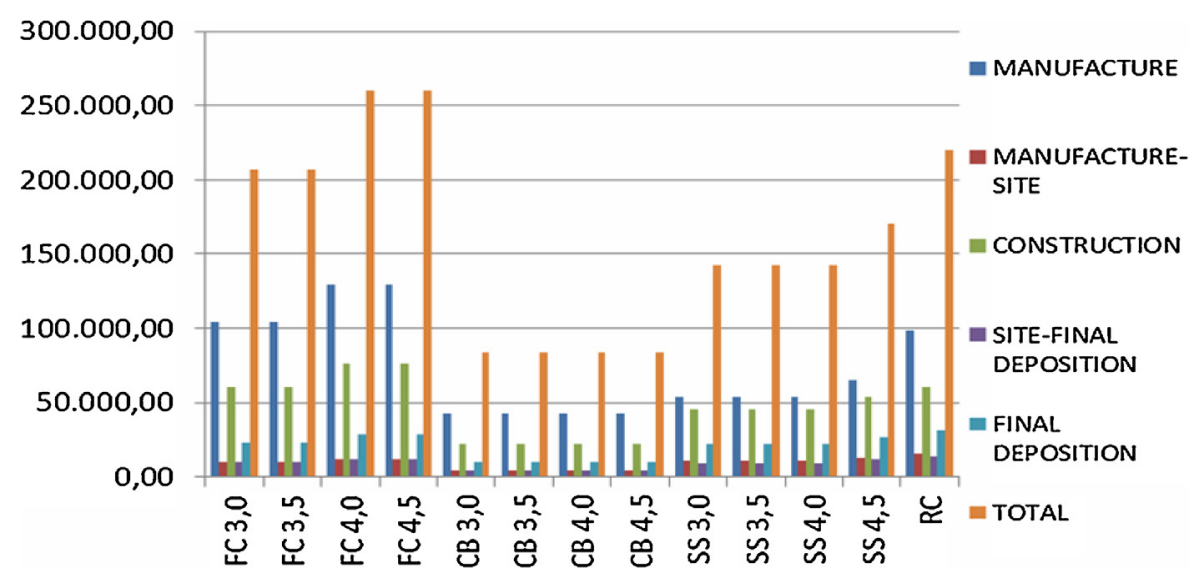

Fig. 6. Cumulative energy demand (MJ) GWP 100a (kg eq- $\left.\mathrm{CO}_{2}\right)$ for each type of load-bearing wall for the two-levels model.

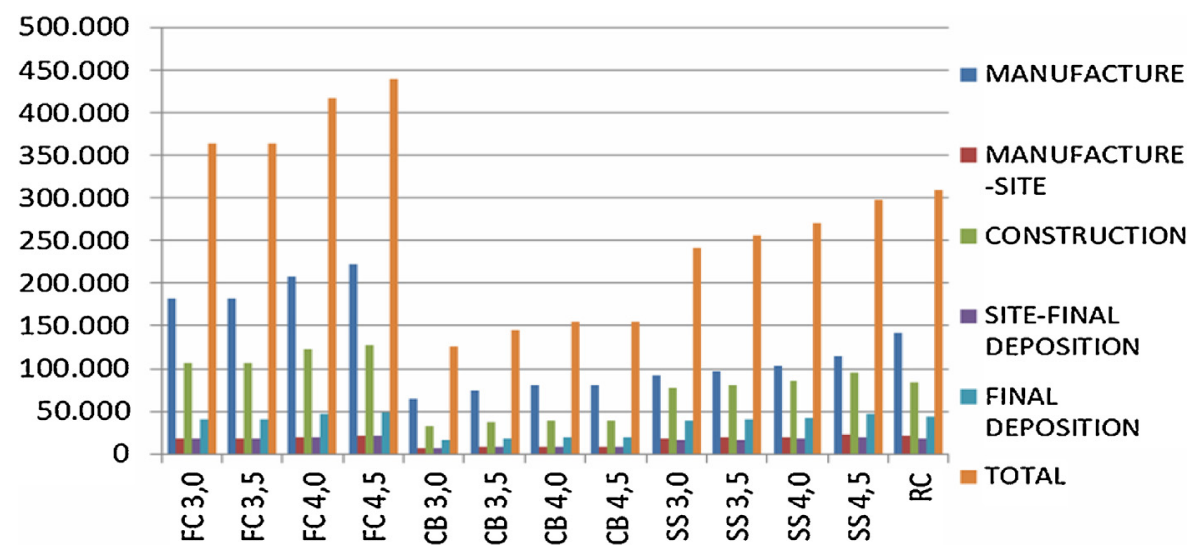

Fig. 7. Cumulative energy demand (MJ) GWP $100 \mathrm{a}\left(\mathrm{kg}\right.$ eq- $\left.\mathrm{CO}_{2}\right)$ for each type of load-bearing wall for the three-levels model.

Table 5

Mean environmental impact values showed by type of material used and building height.

\begin{tabular}{|c|c|c|c|c|c|c|c|}
\hline & \multirow[b]{2}{*}{ GWP Total } & \multicolumn{3}{|c|}{ Global warming potential GWP 100 years (kg eq-CO ${ }_{2}$ ) CML 2001} & \multicolumn{3}{|c|}{ Cumulative energy demand (MJ) } \\
\hline & & $\mathrm{GWP} / \mathrm{m}^{2}$ & Average $\mathrm{GWP} / \mathrm{m}^{2}$ & $\mathrm{CED}(\mathrm{MJ})$ & $\mathrm{CED} / \mathrm{m}^{2}$ & Average $\mathrm{CED} / \mathrm{m}^{2}$ & \\
\hline \multirow[t]{3}{*}{ FC } & 1 level & 7868.38 & 131.14 & 146.21 & $103,585.25$ & 1726.42 & 1957.62 \\
\hline & 2 levels & $17,440.57$ & 145.34 & & $233,683.83$ & 1947.37 & \\
\hline & 3 levels & $29,188.97$ & 162.16 & & $395,834.71$ & 2199.08 & \\
\hline \multirow[t]{3}{*}{$\mathrm{CB}$} & 1 level & 4037.67 & 67.29 & 47.83 & $42,093.77$ & 701.56 & 736.04 \\
\hline & 2 levels & 7980.46 & 66.50 & & $84,100.61$ & 700.84 & \\
\hline & 3 levels & $13,716.86$ & 76.20 & & $145,027.43$ & 805.71 & \\
\hline \multirow[t]{3}{*}{ SS } & 1 level & 4386.23 & 73.10 & 79.68 & $71,145.05$ & 1185.75 & 1303.64 \\
\hline & 2 levels & 9112.18 & 75.93 & & $149,312.04$ & 1244.27 & \\
\hline & 3 levels & $16,201.10$ & 90.01 & & $266,562.54$ & 1480.90 & \\
\hline \multirow[t]{3}{*}{$\mathrm{RC}$} & 1 level & 9230.64 & 153.84 & 153.24 & $109,914.35$ & 1831.91 & 1793.65 \\
\hline & 2 levels & $18,367.88$ & 153.07 & & $219,742.56$ & 1831.19 & \\
\hline & 3 levels & $27,505.15$ & 152.81 & & $309,213.86$ & 1717.85 & \\
\hline
\end{tabular}

would improve the LCA relationship between SS and CB considering that $\mathrm{CB}$ has much less mass comparing to SS, but certainly provides much less thermal comfort than SS.

\section{Conclusions}

The significant findings from this study are:

- In all four materials studied, the LCA phases that most clearly determine the final results are manufacturing and construction. For a three-levels building, in the manufacturing process, the embodied energy is between 38 and $51 \%$ of the total, and the $\mathrm{CO}_{2}$ emissions range from 44 to $72 \%$. In the construction phase the embodied energy is between 25.5 and $31.8 \%$ and the $\mathrm{CO}_{2}$ emissions range from 16.5 to $32 \%$.

- In terms of the distances (span) between walls, stabilized soil block masonry (SS) obtained much better overall LCA results than fired clay brick masonry (FC) or reinforced concrete wall (RC).

- When comparing LCA results between stabilized soil block masonry (SS) and concrete block masonry (CB) for all distances between the walls, SS scored worse than CB. The proportion between these values is increased as the building height is increased. The average embodied energy value calculated for SS, $266,562.54 \mathrm{MJ}$, doubled that obtained for $\mathrm{CB}$, at $145,027.43 \mathrm{MJ}$. Comparing SS and $\mathrm{CB}$ for $\mathrm{CO}_{2}$ emissions, these are less relevant as the difference is only $12 \%$, ranging from an average value of 
$16,201.10 \mathrm{~kg}$ eq- $\mathrm{CO}_{2}$ (SS) to $13,716.86 \mathrm{~kg}$ eq- $\mathrm{CO}_{2}(\mathrm{CB})$. The explanation lies in the difference between total wall mass, which is $2-3$ times higher for SS than for CB.

- The difference in final LCA results increases when the span between walls extends. This establishes a relationship to be taken into account when designing the building structure, between the type and characteristics of the building and the choice of structural material from the embodied energy and $\mathrm{CO}_{2}$ emissions perspective.

\section{Acknowledgments}

The authors wish to acknowledge the IUACC "Instituto Universitario de Arquitectura y Ciencias de la Construcción" for the necessary support to develop this research. We would also like to express our gratitude to the Foundation Innovarcilla, also known as the Andalusian Ceramics Technology Centre.

This research project has been partially funded by the TEP-1988 project PANEL of the 2012 call of the Dirección General de Investigación, Tecnología y Empresa. Consejería de Economía, Innovación, Ciencia y Empleo. Junta de Andalucía.

\section{References}

[1] L.F. Cabeza, L. Rincón, V. Vilariño, G.G. Pérez, A. Castell, Life cycle assessment (LCA) and life cycle energy analysis (LCEA) of buildings and the building sector: a review, Renewable Sustainable Energy Rev. 29 (January) (2014) 394-416.

[2] A. Uihlein, P. Eder, Towards additional policies to improve the environmental performance of buildings JRC Scientific and Technical Report. EUR 23775 EN-2009. Seville, vol. 2009, 2009.

[3] G.A. Blengini, T. Di Carlo, The changing role of life cycle phases, subsystems and materials in the LCA of low energy building, Energy Build. 42 (June) (2010) $869-880$.

[4] ISO, Environmental management-life cycle assessment-principles and framework, in: ISO 14040, CEN, Brussels, 2006.

[5] ISO 14040, Environmental Management-Life Cycle AssessmentRequirements and Guidelines, CEN, Brussels, 2006.

[6] B.V.Venkatarama Reddy, K.S. Jagadish, Embodied energy of common and alternative building materials and technologies, Energy Build. 35 (2003) 129-137.

[7] M. Vázquez, Building and impact on the environment: the case of the earth and other materials (Construcción e impacto sobre el ambiente: el caso de la tierra y otros materlales), Inform. Constr. 52 (471) (2001) 29e43.

[8] G.M.T. Janssen, Ch.F. Hendriks, Sustainable use of recycled materials in building construction, Adv. Build. Technol. 1399 (2002) e406.

[9] P. Walker, Strength, durability and shrinkage characteristics of cement stabilised soil blocks, Cem. Concr. Compos. 17 (4) (1995) 301-310.

[10] H. Houben, H. Guillaud, Earth Construction: A Comprehensive Guide, IT Publications, London, UK, 1994.

[11] P. Walker, B.V. Venkatarama Reddy, A. Mesbah, J.C. Morel, The case for compressed earth block construction, in: Proceedings of 6th International Seminar on Structural Masonry for Developing Countries, Allied Publishers Ltd., Bangalore, India, October, 2000, pp. 27-35.

[12] A. Shukla, G.N. Tiwari, M.S. Sodha, Embodied energy analysis of adobe house, Renewable Energy 34 (3) (2009) 755e61.

[13] M. Asif, T. Muneer, R. Kelley, Life cycle assessment: a case study of a dwelling home in Scotland, Build. Environ. 42 (3) (2007) 1391-1394.

[14] N. Huberman, D. Pearlmutter, A life-cycle energy analysis of building materials in the Negev desert, Energy Build. 40 (2008) 837e48.

[15] C. Thormark, A low energy building in a life cycle e its embodied energy, energy need for operation and recycling potential, Build. Environ. 37 (2002) 429-435.

[16] G.A. Blengini, Life cycle of buildings, demolition and recycling potential: a case study in Turin, Italy, Build. Environ. 44 (2009) 319-330.

[17] T.Y. Chen, J. Burnett, C.K. Chau, Analysis of embodied energy use in the residential building of Hong Kong, Energy 26 (2001) 323-340.

[18] A.H. Buchanan, B.G. Honey, Energy and carbon dioxide implications of building construction, Energy Build. 20 (1994) 205-217.

[19] M. Suzuki, T. Oka, K. Okada, The estimation of energy consumption and $\mathrm{CO}_{2}$ emission due to housing construction in Japan, Energy Build. 22 (1995) 165-169.

[20] T. Oka, M. Suzuki, T. Konnya, The estimation of energy consumption and amount of pollutants due to the construction of buildings, Energy Build. 19 (1993) 303-311.

[21] A. Debnath, S.V. Singh, Y.P. Singh, Comparative assessment of energy requirements for different types of residential buildings in India, Energy Build. 23 (1995) 141-146.

[22] N. Pargana, M. Duarte Pinheiro, J. Dinis Silvestre, J. de Brito, Comparative environmental life cycle assessment of thermal insulation materials of buildings, Energy Build. 82 (2014) 466-481.
[23] K.I. Praseeda, B.V. Venkatarama Reddy, Monto Mani, Embodied energy assess ment of building materials in India using process and input-output analysis, Energy Build. 86 (2015) 677-686.

[24] I. Sartori, A.G. Hestnes, Energy use in the life-cycle of conventional and low energy buildings: a review article, Energy Build. 39 (2007) 249-257.

[25] S. Kotaji, S. Edwards, A. Schuurmans, Life cycle assessment in building and construction, in: A State-of-the-Art Report, SETAC Press, Florida, 2003.

[26] D. Kellenberger, J. Althaus H-, Relevance of simplifications in LCA of building components, Build. Environ. 44 (2009) 818-825.

[27] M. Khasreen, P. Banfill, G. Menzies, Life-cycle assessment and the environmental impact of buildings: a review, Sustainability 1 (3) (2009) 674-701.

[28] S. Serrano, C. Barreneche, L. Rincón, D. Boer, L. Cabeza, Optimization of three new compositions of stabilized rammed earth incorporating PCM: thermal properties characterization and LCA, Constr. Build. Mater. 47 (2013) 872-878.

[29] M.D. Saghafi, Z.S.H. Teshnizi, Recycling value of building materials in building assessment systems, Energy Build. 43 (2011) 3181-3188.

[30] J. Goggins, T. Keane, A. Kelly, The assessment of embodied energy in typical reinforced concrete building structures in Ireland, Energy Build. 42 (2010) 735-744.

[31] T.J. Wen, H.C. Siong, Z.Z. Noor, Assessment of embodied energy and global warming potential of building construction using life cycle analysis approach: case studies of residential buildings in Iskandar Malaysia, Energy Build. (2014) http://dx.doi.org/10.1016/j.enbuild.2014.12.002

[32] A. Pérez-Garcíaa, A. Guardiola Víllora, González G. Pérez, Building’s ecoefficiency improvements based on reinforced concrete multilayer structural panels, Energy Build. 85 (2014) 1-11.

[33] D. Bansal, R. Singh, R.L. Sawhney, Effect of construction materials on embodied energy and cost of buildings-a case study of residential houses in India up to $60 \mathrm{~m}^{2}$ of plinth area, Energy Build. 69 (2014) 260-266.

[34] H. Monteiro, F. Freire, Life-cycle assessment of a house with alternative exterior walls: comparison of three impact assessment methods, Energy Build. 47 (2012) 572-583.

[35] A. de Gracia, L. Rincón, A. Castell, M. Jiménez, D. Boer, M. Medrano, L.F. Cabeza Life cycle assessment of the inclusion of phase change materials (PCM) in experimental buildings, Energy Build. 42 (2010) 1517-1523.

[36] J. Giesekam, J. Barrett, P. Taylor, A. Owen, The greenhouse gas emissions and mitigation options for materials used in UK construction, Energy Build. 78 (2014) 202-214.

[37] G. Han, J. Srebric, E. Enache-Pommer, Variability of optimal solutions for building components based oncomprehensive life cycle cost analysis, Energy Build. 79 (2014) 223-231.

[38] M.K. Dixit, J.L. Fernández-Solís, S. Lavy, C.H. Culp, Identification of parameters for embodied energy measurement: a literature review, Energy Build. 42 (2010) 1238-1247

[39] T. Ramesh, R. Prakash, K.K. Shukla, Life cycle energy analysis of buildings: an overview, Energy Build. 42 (2010) 1592-1600.

[40] M. Weißenberger, W. Jensch, W. Lang, The convergence of life cycle assessment and nearly zero-energy buildings: the case of Germany, Energy Build. 76 (2014) 551-557.

[41] R. Moschetti, L. Mazzarella, N. Nord, An overall methodology to define reference values for building sustainability parameters, Energy Build. 88 (2015) 413-427.

[42] E. Breviglieri Pereira de Castro, M. Mequignon, L. Adolphe, P. Koptschitz, Impact of the lifespan of different external walls of buildings on greenhouse gas emissions under tropical climate conditions, Energy Build. 76 (2014) 228-237.

[43] C. Baek, S. Park, M. Suzuki, S. Lee, Life cycle carbon dioxide assessment tool for buildings in the schematic design phase, Energy Build. 61 (2013) 275-287.

[44] D.H. Yeo, R.D. Gabbai, Sustainable design of reinforced concrete structures through embodied energy optimization, Energy Build. 43 (2011) 2028-2033.

[45] P.F. Chapman, The energy costs of materials, Energy Policy (1975) 47-57.

[46] E. Worell, R.J.J. Van Heuningen, J.F.M. De Castro, New gross energy requirement figures for material production, Energy 19 (6) (1994) 627-640.

[47] R. Frischknecht, N. Jungbluth, H.J. Althaus, G. Doka, R. Dones, T. Heck, et al., The ecoinvent database: overview and methodological framework, Int. J. Life Cycle Assess. 10 (2005) 3-9.

[48] European Standard, Specification for mortar for masonry. Part 2: Masonry mortar, in: EN-998-2:2012, 2012

[49] W.K. Biswas, W.K. Graham, J.K. Kelly, M.B. John, Global warming contributions from wheat, sheep, meat and wool production in Victoria, Australia-a life cycle assessment, J. Cleaner Prod. 18 (2010) 1386-1392.

[50] E.P. Resurreccion, L.M. Colosi, M.A. White, A.F. Clarens, Comparison of algae cultivation methods for bioenergy production using a combined life cycle assessment and life cycle costing approach, Bioresour. Technol. 126 (2012) 298-306.

[51] I. Zabalza Bribián, A. Aranda Usón, S. Scarpellini, Life cycle assessment in buildings: state-of-the-art and simplified LCA methodology as a complement for building certification, Build. Environ. 44 (2009) 2510-2520.

[52] A. Garcia-Martinez, Life Cycle Assessment (LCA) of Buildings. Methodologica Proposal for the Development of Environmental Declarations of Dwellings in Andalusia, Universidad de Sevilla, Sevilla, España, 2010 (Doctoral Dissertation). 〈http://fondosdigitales.us.es/media/thesis/1546/Q_Tesis_AGM.pdf〉.

[53] D. Kellenberger, et al., Life Cycle Inventories of Building Products. Data v1.1. Ecoinvent Report n 7, Swiss Centre for Life Cycle Inventories, Dübendorf, Swiss, 2004. 